\title{
Rheumatoid arthritis and metabolic syndrome
}

\author{
Viviane Roseli da Cunha', Claiton Viegas Brenol², \\ João Carlos Tavares Brenol ${ }^{3}$, Ricardo Machado Xavier ${ }^{4}$
}

\begin{abstract}
In the past 20 years, the life expectancy of patients with rheumatoid arthritis (RA) has been shown to be reduced by three to ten years as compared to that of the general population. Currently, cardiovascular disease (CVD) is the major cause of death in patients with RA, and acute myocardial infarction can be up to four times more frequent in these patients. The autoimmune systemic inflammatory response, along with the presence of metabolic syndrome (MetS), doubles the risk for fatal or non-fatal CVD and coronary atherosclerosis, regardless of age and sex. Rheumatoid arthritis has been associated with increased prevalence of MetS, but its role in the different characteristics of the disease, such as disease duration, activity, and treatment with glucocorticoids, is not well defined. This study aimed at reviewing the prevalence of MetS and the factors implicated in the development of atherosclerosis in RA patients, assessing the clinical aspects of RA and its association with the development of MetS.
\end{abstract}

Keywords: metabolic syndrome X, rheumatoid arthritis, cardiovascular diseases.

[Rev Bras Reumatol 2011;51(3):260-8] CElsevier Editora Ltda

\section{INTRODUCTION}

Rheumatoid arthritis (RA) is a systemic inflammatory disorder characterized by chronic symmetric and erosive synovitis that affects preferentially peripheral joints. ${ }^{1}$ Patients with RA have a reduced life expectancy, ${ }^{2}$ which is associated with an increased risk for cardiovascular events. ${ }^{3,4}$ They have a fourfold increased frequency of acute myocardial infarction. ${ }^{5}$ Accelerated coronary ${ }^{3}$ and extracoronary ${ }^{2}$ atherosclerosis is a characteristic of RA, and its pathogenesis has not been clearly defined. ${ }^{6}$ The high prevalence of traditional cardiovascular risk factors and the systemic inflammatory process play a role in this pathogenesis. There is evidence of an inflammatory basis for atherosclerosis, which has led many researchers to study the relationship between systemic inflammatory conditions, such as RA, and the risk for coronary heart disease..$^{7-9}$ Metabolic syndrome (MetS), a set of cardiovascular risk factors (such as central obesity, dyslipidemia, hypertension, and hyperglycemia), has been assessed aiming at predicting the risk for cardiovascular disease (CVD). ${ }^{3}$ There is evidence showing the association between RA, its inflammatory activity, and MetS, ${ }^{2,3}$ but the results on the prevalence of this syndrome in RA are conflicting. $2,3,6,10,11$

This study aimed at reviewing the prevalence of MetS and the factors involved in the development of atherosclerosis in RA patients, assessing the clinical aspects of RA and their association with the development of MetS.

\section{DEFINITION CRITERIA OF \\ METABOLIC SYNDROME}

Metabolic syndrome can increase up to two fold the risk for CVD. ${ }^{12}$ The most accepted hypothesis for the development of MetS indicates insulin resistance (IR) as the major pathophysiological mediator. ${ }^{13}$

There have been several attempts to define MetS in literature (Table 1). The World Health Organization (WHO) established in 1999 the criteria for defining MetS (modified in 2004). ${ }^{14}$ Alternative definitions have been subsequently proposed by the European Group for the Study of Insulin Resistance

Received on 2/4/2011. Approved on 2/15/2011. Financial support: Coordenação de Aperfeiçoamento de Pessoal de Ensino Superior (Capes), Fundo de Incentivo a Pesquisa e Eventos - Fipe. Authors declare no conflicts of interest.

Universidade Federal do Rio Grande do Sul - UFRGS, Brazil.

1. Master in Medical Sciences by the UFRGS; Rheumatologist at Hospital Universitário de Santa Maria

2. PhD in Medical Sciences by the UFRGS; Coordinator of the Hospital de Clínicas de Porto Alegre

3. Professor and Chief of the Department of Internal Medicine at UFRGS; PhD in Medicine by the UFRGS

4. Professor of the Department of Internal Medicine at Medical School of the UFRGS; PhD in Immunology by the Shimane University, Japan; Chief of the Rheumatology Service of the HCPA

Correspondence to: Claiton Viegas Brenol. Serviço de Reumatologia do Hospital das Clínicas de Porto Alegre. Rua Ramiro Barcelos, 2.350, sala 645. Porto Alegre, RS, Brasil. CEP: 90035-003. E-mail: claiton.brenol@gmail.com 
$(\text { EGIR) })^{15}$ in 1999 and by the Adult Treatment Panel III of the National Cholesterol Education Program (NCEP ATP III) American Heart Association (AHA) in 2001. The NCEP III was last updated in 2005. ${ }^{16}$ The American Association of Clinical Endocrinologists (AACE), ${ }^{17}$ in 2003, and the International Diabetes Federation (IDF), ${ }^{18}$ in 2004, have also proposed their criteria for defining MetS.

All definitions include measuring systemic blood pressure, triglycerides, high-density lipoprotein cholesterol (HDL-C), and fasting glycemia. They differ regarding the cutoff points of their components and the criteria of obesity. The WHO and EGIR definitions require the presence of IR in the first, and IR or hyperinsulinemia in the second. The definition of the NCEPATP III is based only on the number of abnormalities, ${ }^{3}$ while the IDF definition is based on central obesity, which requires an increased waist circumference. The AACE definition of MetS requires high risk for IR or body mass index (BMI) $\geq 25 \mathrm{~kg} / \mathrm{m}^{2}$ or waist $\geq 102 \mathrm{~cm}$ (men) $/ \geq 88 \mathrm{~cm}$ (women).

\section{PREVALENCE OF METABOLIC SYNDROME IN BRAZIL}

A study carried out by Nakazone et al. ${ }^{19}$ in the city of São José do Rio Preto, São Paulo state, in 2007, assessed 340 individuals (200 patients and 140 controls), paired for sex and age. The patients were on regular follow-up with a cardiologist, and the presence of risk factors for CVD was considered, aiming at primary or secondary prevention. Individuals with no routine cardiology follow-up were included in the control group. According to the NCEP-ATPIII (2001) criteria, $35.5 \%$ of patients and $8.6 \%$ of controls $(\mathrm{P}<0.0001)$ had MetS. The IDF criteria evidenced MetS in $46 \%$ of patients and in $17.9 \%$ of controls $(\mathrm{P}<0.0001)$.

Another Brazilian study, assessing the existence of an association between periodontal disease and MetS in 1,315 Japanese-Brazilians aged between 30 and 92 years, regardless of oral health conditions, has reported a $54 \%$ prevalence of MetS according to the NCEP 2001 definition. ${ }^{20}$

Table 1

Current definitions of metabolic syndrome

\begin{tabular}{|c|c|c|c|c|c|}
\hline Parameters & NCEP ATP III 2005 & IDF 2005 & EGIR 1999 & WHO 1999 modified & AACE 2003 \\
\hline Required & & $\begin{array}{l}\text { Waist } \\
\geq 94 \mathrm{~cm} \text { (men) or } \\
\geq 80 \mathrm{~cm} \text { (women) * }\end{array}$ & $\begin{array}{l}\text { IR or fasting } \\
\text { hyperinsulinemia at the } \\
\text { top of the } 25 \text { th percentile }\end{array}$ & $\begin{array}{l}\text { IR: HOMA at the top } \\
\text { of the } 25 \text { th percentile, } \\
\text { fasting glycemia } \\
\geq 110 \text { or DM }\end{array}$ & $\begin{array}{l}\text { At high risk for IR } \\
\Delta \text { or BMI } \geq 25 \text { or } \\
\text { waist } \geq 102 \text { (men) } \\
\text { or } \geq 88 \text { (women) }\end{array}$ \\
\hline $\begin{array}{l}\text { Number of } \\
\text { abnormalities }\end{array}$ & $\geq 3$ of: & $\geq 2$ of: & $\geq 2$ of: & $\geq 2$ of: & $\geq 2$ of: \\
\hline Glucose & $\begin{array}{l}\geq 100 \mathrm{mg} / \mathrm{dL} \text { or } \\
\text { treatment with a drug } \\
\text { for high glycemia }\end{array}$ & $\begin{array}{l}\geq 100 \mathrm{mg} / \mathrm{dL} \text { or } \\
\text { DM diagnosis }\end{array}$ & $110-125 \mathrm{mg} / \mathrm{dL}$ & & $\begin{array}{l}\geq 110 ; \geq 140 \mathrm{mg} / \mathrm{dL} \\
2 \mathrm{~h} \text { after glucose }\end{array}$ \\
\hline HDL-C & $\begin{array}{l}<40 \text { (men); }<50 \\
\text { (women) or treatment } \\
\text { with a drug for } \\
\text { low HDL-c } \diamond\end{array}$ & $\begin{array}{l}<40 \text { (men); }<50 \\
\text { (women) or treatment } \\
\text { with a drug for } \\
\text { low HDL-c }\end{array}$ & $<40 \mathrm{mg} / \mathrm{dL}$ & $\begin{array}{l}<35 \text { (men) } \\
<40 \text { (women) }\end{array}$ & $\begin{array}{l}<40 \text { (men) } \\
<50 \text { (women) }\end{array}$ \\
\hline Triglycerides & $\begin{array}{l}\geq 150 \mathrm{mg} / \mathrm{dL} \text { or } \\
\text { treatment with a } \\
\text { drug for high } \\
\text { triglycerides } \diamond\end{array}$ & $\begin{array}{l}\geq 150 \mathrm{mg} / \mathrm{dL} \text { or } \\
\text { treatment with a } \\
\text { drug for high } \\
\text { triglycerides }\end{array}$ & $\begin{array}{l}\text { Or } \geq 180 \mathrm{mg} / \mathrm{dL} \text { or } \\
\text { treatment with a drug } \\
\text { for dyslipidemia }\end{array}$ & Or $\geq 150 \mathrm{mg} / \mathrm{dL}$ & $\geq 150 \mathrm{mg} / \mathrm{dL}$ \\
\hline Obesity & $\begin{array}{l}\text { Waist } \geq 102 \mathrm{~cm} \text { (men) } \\
\text { or } \geq 88 \mathrm{~cm} \text { (women) } \S\end{array}$ & & $\begin{array}{l}\text { Waist } \geq 94 \mathrm{~cm} \text { (men) } \\
\text { or } \geq 80 \mathrm{~cm} \text { (women) }\end{array}$ & $\begin{array}{l}\text { Waist } \geq 94 \mathrm{~cm} \text { (men) } \\
\text { or } \geq 88 \mathrm{~cm} \text { (women) }\end{array}$ & \\
\hline Hypertension & $\begin{array}{l}\geq 130 / 85 \mathrm{mmHg} \\
\text { or treatment with } \\
\text { a drug for SAH }\end{array}$ & $\begin{array}{l}\geq 130 / 85 \mathrm{mmHg} \\
\text { or treatment with } \\
\text { a drug for SAH }\end{array}$ & $\begin{array}{l}\geq 140 / 90 \mathrm{mmHg} \\
\text { or treatment with } \\
\text { a drug for SAH }\end{array}$ & $\begin{array}{l}\geq 140 / 90 \mathrm{mmHg} \\
\text { or treatment with } \\
\text { a drug for SAH }\end{array}$ & $\geq 130 / 85 \mathrm{mmHg}$ \\
\hline
\end{tabular}

NCEP: National Cholesterol Education Program; IDF: International Diabetes Federation; EGIR: Group for the Study of Insulin Resistance; WHO: World Health Organization; AACE: American Association of Clinical Endocrinologists; HDL-C: high-density lipoprotein cholesterol; HOMA: homeostasis model assessment; BMl: body mass index; SAH: systemic arterial hypertension; IR: insulin resistance; DM: diabetes mellitus.

* For South-Asian and Chinese patients, waist $\geq 90 \mathrm{~cm}$ (men) or $\geq 80 \mathrm{~cm}$ (women); for Japanese patients, waist $\geq 90$ (men) or $\geq 80 \mathrm{~cm}$ (women).

$\triangle$ At high risk for IR, indicated by the presence of at least one of the following: diagnosis of CVD, hypertension, polycystic ovary syndrome, non-alcoholic fatty liver disease, or acanthosis nigricans; family history of type 2 diabetes, hypertension or CVD; history of gestational diabetes or glucose intolerance; non-white ethnicity; sedentary lifestyle; $\mathrm{BMl}=25 \mathrm{~kg} / \mathrm{m}^{2}$ or waist circumference $=94 \mathrm{~cm}$ for men and $=80 \mathrm{~cm}$ for women; and age de 40 years.

$\diamond$ Treatment with one or more fibrates or niacin.

$\S$ In Asian patients, waist $\geq 90 \mathrm{~cm}$ (men) or $\geq 80 \mathrm{~cm}$ (women).

Adapted from Meigs. ${ }^{25}$ 
In 2004, Velásquez-Meléndez et al. ${ }^{21}$ carried out a crosssectional population-based study in Virgem das Graças, a rural community located in Vale do Jequitinhonha, state of Minas Gerais. The study comprised 251 individuals (117 men and 134 women), whose ages ranged from 20 to 88 years. The prevalence of MetS according to the NCEP 2001 definition was $21.6 \%$ (7.7\% for men and $33.6 \%$ for women). The overall prevalence adjusted for age was $19.0 \%$.

In 2006, a population-based study conducted in the rural district of Cavunge, in the semi-arid region of the state of Bahia, assessed the prevalence of MetS according to the NCEP/ATPIII 2001 criteria in a random sample consisting of 240 individuals (102 men and 138 women; age range, 25 to 87 years). The raw prevalence of MetS was $30.0 \%$, and, after adjusting for age, $24.8 \%{ }^{22}$

Salaroli et al. ${ }^{23}$ have reported a $29.8 \%$ prevalence of MetS (without difference between sexes) in a random sample of 1,663 individuals (25-64 years) in the city of Vitoria, state of Espírito Santo, according to the NCEP/ ATPIII 2001 criteria.

\section{CRITICAL OVERVIEW OF METABOLIC SYNDROME}

In addition to the sum of the individual components of MetS, ${ }^{2}$ this cluster of risk factors is believed to play an important role in increasing the risk for CVD. Likewise, the existence of a single pathophysiological basis, IR, ${ }^{3}$ is believed to explain the syndrome. However, a consensus about it has not been achieved.

The American Diabetes Association and the European Association for the Study of Diabetes have issued a joint declaration questioning the classification of the components of MetS as a true "syndrome". The arguments were as follows: lack of definition clarity, with different criteria in existing definitions; different and multiple phenotypes included in MetS, with consequent different treatment strategies; lack of a consistent evidence basis for entering several components in the definitions; inclusion of patients with clinical CVD or diabetes as part of the syndrome, which is intended to define risk for these diseases; unclear pathogenesis linking the components of MetS: there is the possibility that IR is not the underlying condition of all factors, and it is not a consistent finding in some definitions; other risk factors for CVD, which are not components of MetS, such as inflammatory markers, may carry an equal or greater risk; and, finally, the MetS-associated risk for CVD has not shown to be greater than the sum of the individual components. ${ }^{24}$
Despite questions about the existence of MetS, it is undoubtedly paramount to identify the presence of its components and establish the adequate management strategies so that the morbidity and mortality associated with diabetes and CVD can be reduced. ${ }^{25}$

The etiology of MetS is unknown, but it is likely to involve a complex interaction of genetic, environmental, and metabolic factors. Results of several studies have suggested that the proinflammatory state can contribute to the development of MetS. ${ }^{20}$

\section{METABOLIC SYNDROME IN RHEUMATOID ARTHRITIS}

The interest in identifying MetS in patients with RA has emerged recently, justified by the need to better understand the determinant factors of CVD in these patients (Table 2).

In 2002, the first study assessing the hypothesis that the increased prevalence of interrelated cardiovascular risk (CV risk factors) factors determines the presence of MetS in RA had patients with osteoarthritis (OA) as the control group. The authors reported that more patients with RA had IR and low HDL levels as compared with patients with OA, and both were directly associated with C-reactive protein levels. Moreover, IR, low HDL levels, hypertriglyceridemia, and hypertension were associated with each other in the rheumatoid group, which was not observed in patients with OA. ${ }^{26}$

To assess the effects of glucocorticoids on CVD of patients with RA, Dessein et al. ${ }^{5}$ have tested the effects of glucocorticoids on traditional CV risk factors factors. The use of prednisone and its frequent intramuscular, intra-articular, and intravenous doses have been associated with the presence of IR $(\mathrm{P}<0.05)$. The use of glucocorticoids has not been associated with obesity, dyslipidemia, or hypertension. In 2006, the same research team assessed the association of MetSrelated CV risk factors factors with the presence of subclinical atherosclerosis using ultrasound measurement of plaques and the common carotid intima and media layer thickness. Hypertension, IR, and hypertriglyceridemia were independent risk factors for subclinical atherosclerosis $(\mathrm{P}=0.02,0.04$, and 0.05 , respectively). In this study, individual risk factors were more strongly associated with subclinical atherosclerosis than with the MetS definitions. ${ }^{10}$

In 2008, Chung et al. ${ }^{2}$ demonstrated for the first time an increase in MetS prevalence in patients with RA when compared with controls adjusted for age, race, and sex. Using the WHO definition, the frequency of MetS was greater in patients with long-term disease (42\%) when compared to patients with early arthritis $(30 \%)$ and controls $(11 \%)(\mathrm{P}<0.001)$. The authors 
Table 2

Prevalence of metabolic syndrome in rheumatoid arthritis

\begin{tabular}{|c|c|c|c|c|}
\hline Author, year (reference) & Study & Sample & Criteria for defining MetS & Prevalence of MetS \\
\hline Chung et al., 2008² & Case-control & $\begin{array}{l}154 \text { patients } \\
85 \text { controls }\end{array}$ & $\begin{array}{l}\text { NCEP } 2001 \text { and } \\
\text { WHO modified }\end{array}$ & $\begin{array}{l}\text { Long-term RA } 42 \% \text {, initial RA } 30 \% \text {, } \\
\text { and controls } 22 \% \text { (NCEP 2001); } \\
\text { Long-term RA } 42 \% \text {, initial RA } \\
31 \% \text {, and controls } 11 \% \text { (WHO) }\end{array}$ \\
\hline Karvounaris et al., $2007^{3}$ & Case-control & $\begin{array}{l}200 \text { patients } \\
400 \text { controls }\end{array}$ & NCEP 2001 & $\begin{array}{l}\text { RA } 44 \% \\
\text { Controls } 41 \%\end{array}$ \\
\hline Dessein et al., 2006 ${ }^{10}$ & Cross-sectional & 74 patients & $\begin{array}{l}\text { NCEP } 2005 \text { and } \\
\text { WHO modified }\end{array}$ & $\begin{array}{l}\text { RA 19\% (NCEP 2005); } \\
\text { RA } 14 \% \text { (WHO) }\end{array}$ \\
\hline Elkan et al., $2009^{11}$ & Cross-sectional & 80 patients & IDF & $\begin{array}{l}\text { Women with RA } 20 \% \\
\text { Men with RA } 63 \%\end{array}$ \\
\hline La Montagna et al., $2007^{6}$ & Case-control & $\begin{array}{l}45 \text { patients } \\
48 \text { controls }\end{array}$ & NCEP 2005 & $\begin{array}{l}\text { RA } 55.5 \% \\
\text { Controls } 45.8 \%\end{array}$ \\
\hline Toms et al., $2009^{29}$ & Cross-sectional & 400 patients & $\begin{array}{l}\text { IDF, NCEP 2004, NCEP } \\
\text { 2001, WHO, EGIR }\end{array}$ & $\begin{array}{l}45.3 \% \text { (IDF) } \\
40.1 \% \text { (NCEP 2004) } \\
38.3 \% \text { (NCEP 2001) } \\
19.4 \% \text { (WHO) } \\
12.1 \% \text { (EGIR) }\end{array}$ \\
\hline Giles et al., 2010 & Case-control & $\begin{array}{l}131 \text { patients } \\
121 \text { controls }\end{array}$ & NCEP 2005 & $\begin{array}{l}\text { RA } 36 \% \\
\text { Controls } 27 \%\end{array}$ \\
\hline
\end{tabular}

NCEP: National Cholesterol Education Program; WHO: World Health Organization; IDF: International Diabetes Federation; EGIR: Group for the Study of Insulin Resistance.

also assessed the presence of atherosclerosis using detection of coronary calcifications on electron beam computed tomography. In RA group, patients with MetS according to the WHO definition were at an increased risk for higher coronary artery calcification scores, regardless of age and $\operatorname{sex}(\mathrm{OR}=2.02 ; 95 \%$ CI: 1.03-3.97; $\mathrm{P}=0.04)$.

Some authors have found conflicting results regarding the aforementioned studies. Karvounaris et $a l .^{3}$ reported no statistically significant difference between cases and controls regarding the presence of MetS. The authors have studied 200 patients with RA and 400 controls adjusted for age and sex. The total prevalence of MetS, according to the NCEP 2001 definition, was $44 \%$ in patients with RA and $41 \%$ in controls $(\mathrm{P}=0.5)$. In another study, La Montagna et al. ${ }^{6}$ assessed 45 patients with RA and 48 controls with no systemic rheumatologic disease. The prevalence of MetS, according to the updated NCEP definition, was $55.5 \%$ in patients with RA and $45.8 \%$ in patients without RA. In the study, no significant difference was observed between cases and controls.

In 2010, North-American researchers assessed the presence of CV risk factors factors and the NCEP III criteria for MetS in a case-control study with 131 patients with RA and 121 controls. ${ }^{27}$ The difference in prevalence of MetS was not statistically significant between patients and controls (36\% versus $27 \% ; \mathrm{P}=0.12$; respectively). These authors quantified the visceral and subcutaneous fat by use of computed tomography.
The abdominal fat distribution differed significantly depending on RA activity, and was more significantly associated with CV risk factors factors in patients than in controls.

Non-controlled studies have also assessed the prevalence of MetS in RA. Elkan et al., ${ }^{11}$ differently from the previous studies, used the IDF criteria for determining the prevalence of MetS in 80 patients (61 women and 19 men) with RA. They have reported a MetS prevalence of $20 \%$ for women and $63 \%$ for men. In 2009 , Toms et al. ${ }^{28}$ assessed the prevalence of MetS in 400 patients with RA using five definitions (NCEP 2004 and 2001, IDF, WHO, and EGIR). The highest prevalence was $45.3 \%$ according to IDF, and the lowest prevalence was $12.1 \%$ according to EGIR.

\section{CONCLUSIONS}

Based on current knowledge, one can state that patients with RA are at a higher risk for developing CVD than general population. Studies about the prevalence of MetS in this population of patients have not achieved definitive conclusions, although its presence has been directly associated with a worse prognosis and disease activity. By itself, the later aspect suggests that a better control of underlying disease inflammatory process may improve both articular and CV prognoses in these patients. Monitoring and early identification of CV risk factors factors should be a necessary and constant preoccupation of rheumatologists caring for patients with RA. 


\section{REFERENCES}

\section{REFERÊNCIAS}

1. Kelley WN, Ruddy, S., Sledge, C.B. eds. Textbook of rheumatology. 5 ed. Philadelphia: WB Saunders, 1997.

2. Chung CP, Oeser A, Solus JF, Avalos I, Gebretsadik T, Shintani A et al. Prevalence of the metabolic syndrome is increased in rheumatoid arthritis and is associated with coronary atherosclerosis. Atherosclerosis 2008; 196(2):756-63.

3. Karvounaris SA, Sidiropoulos PI, Papadakis JA, Spanakis EK, Bertsias GK, Kritikos HD et al. Metabolic syndrome is common among middle-to-older aged Mediterranean patients with rheumatoid arthritis and correlates with disease activity: a retrospective, crosssectional, controlled, study. Ann Rheum Dis 2007; 66(1):28-33.

4. del Rincon ID, Williams K, Stern MP, Freeman GL, Escalante A. High incidence of cardiovascular events in a rheumatoid arthritis cohort not explained by traditional cardiac risk factors. Arthritis Rheum 2001; 44(12):2737-45.

5. Dessein PH, Joffe BI, Stanwix AE, Christian BF, Veller M. Glucocorticoids and insulin sensitivity in rheumatoid arthritis. J Rheumatol 2004; 31(5):867-74.

6. La Montagna G, Cacciapuoti F, Buono R, Manzella D, Mennillo GA, Arciello A et al. Insulin resistance is an independent risk factor for atherosclerosis in rheumatoid arthritis. Diab Vasc Dis Res 2007; 4(2):130-5.

7. Maradit-Kremers H, Crowson CS, Nicola PJ, Ballman KV, Roger $\mathrm{VL}$, Jacobsen SJ et al. Increased unrecognized coronary heart disease and sudden deaths in rheumatoid arthritis: a population-based cohort study. Arthritis Rheum 2005; 52(2):402-11.

8. Brenol CV, Monticielo OA, Xavier RM, Brenol JC. Rheumatoid arthritis and atherosclerosis. Rev Assoc Med Bras 2007; 53(5):46570 .

9. Torigoe DY, Laurindo IdMMe. Artrite reumatóide e doenças cardiovasculares. Rev Bras Reumatol 2006; 46:60-6.

10. Dessein PH, Tobias M, Veller MG. Metabolic syndrome and subclinical atherosclerosis in rheumatoid arthritis. J Rheumatol 2006; 33(12):2425-32.

11. Elkan AC, Hakansson N, Frostegard J, Cederholm T, Hafstrom I. Rheumatoid cachexia is associated with dyslipidemia and low levels of atheroprotective natural antibodies against phosphorylcholine but not with dietary fat in patients with rheumatoid arthritis: a crosssectional study. Arthritis Res Ther 2009; 11(2):R37.

12. Dekker JM, Girman C, Rhodes T, Nijpels G, Stehouwer CD, Bouter LM et al. Metabolic syndrome and 10-year cardiovascular disease risk in the Hoorn Study. Circulation 2005; 112(5):666-73.

13. Eckel RH, Grundy SM, Zimmet PZ. The metabolic syndrome. Lancet 2005; 365(9468):1415-28.
14. Reilly MP, Wolfe ML, Rhodes T, Girman C, Mehta N, Rader DJ Measures of insulin resistance add incremental value to the clinical diagnosis of metabolic syndrome in association with coronary atherosclerosis. Circulation 2004; 110(7):803-9.

15. Beck-Nielsen H. General characteristics of the insulin resistance syndrome: prevalence and heritability. European Group for the study of Insulin Resistance (EGIR). Drugs 1999; 58 Suppl 1:7-10, discussion 75-82.

16. 16. Grundy SM, Cleeman JI, Daniels SR, Donato KA, Eckel RH, Franklin BA et al. Diagnosis and management of the metabolic syndrome: an American Heart Association/National Heart, Lung, and Blood Institute Scientific Statement. Circulation 2005; 112(17):2735-52.

17. Einhorn D, Reaven GM, Cobin RH, Ford E, Ganda OP, Handelsman $\mathrm{Y}$ et al. American College of Endocrinology position statement on the insulin resistance syndrome. Endocr Pract 2003; 9(3):237-52.

18. Alberti KG, Zimmet P, Shaw J. Metabolic syndrome: a new worldwide definition. A consensus statement from the International Diabetes Federation. Diabet Med 2006; 23(5):469-80.

19. Nakazone MA, Pinheiro A, Braile MC, Pinhel MA, de Sousa GF, Pinheiro S, Jr. et al. Prevalence of metabolic syndrome using NCEPATPIII and IDF definitions in Brazilian individuals. Rev Assoc Med Bras 2007; 53(5):407-13.

20. Borges PK, Gimeno SG, Tomita NE, Ferreira SR. Prevalence and characteristics associated with metabolic syndrome in JapaneseBrazilians with and without periodontal disease. Cad Saude Publica 2007; 23(3):657-68.

21. Velasquez-Melendez G, Gazzinelli A, Correa-Oliveira R, Pimenta AM, Kac G. Prevalence of metabolic syndrome in a rural area of Brazil. São Paulo Med J 2007; 125(3):155-62.

22. de Oliveira EP, de Souza ML, de Lima MD. Prevalence of metabolic syndrome in a semi-arid rural area in Bahia. Arq Bras Endocrinol Metabol 2006; 50(3):456-65.

23. Salaroli LB, Barbosa GC, Mill JG, Molina MC. Prevalence of metabolic syndrome in population-based study, Vitoria, ES-Brazil. Arq Bras Endocrinol Metabol 2007; 51(7):1143-52.

24. Kahn R, Buse J, Ferrannini E, Stern M. The metabolic syndrome: time for a critical appraisal: joint statement from the American Diabetes Association and the European Association for the Study of Diabetes. Diabetes Care 2005; 28(9):2289-304.

25. Meigs JB. Metabolic syndrome: in search of a clinical role. Diabetes Care 2004; 27(11):2761-3.

26. Dessein PH, Stanwix AE, Joffe BI. Cardiovascular risk in rheumatoid arthritis versus osteoarthritis: acute phase response related decreased insulin sensitivity and high-density lipoprotein cholesterol as well as clustering of metabolic syndrome features in rheumatoid arthritis. Arthritis Res 2002; 4(5):R5.

27. Giles JT, Allison M, Blumenthal RS, Post W, Gelber AC, Petri M et al. Abdominal adiposity in rheumatoid arthritis: association with cardiometabolic risk factors and disease characteristics. Arthritis Rheum 2010; 62(11):3173-82.

28. Toms TE, Panoulas VF, John H, Douglas KM, Kitas GD. Methotrexate therapy associates with reduced prevalence of the metabolic syndrome in rheumatoid arthritis patients over the age of 60- more than just an anti-inflammatory effect? A cross sectional study. Arthritis Res Ther 2009; 11(4):R110. 